\title{
Spatial distribution of soda straws growth rates of the Coufin Cave (Vercors, France).
}

\author{
Yves Perrette ${ }^{1}$ and Stéphane Jaillet ${ }^{1}$
}

\begin{abstract}
:
Perrette Y. and Jaillet S. 2010. Spatial distribution of soda straws growth rates of the Coufin Cave (Vercors, France). International Journal of Speleology, 39(2), 61-70. Bologna (Italy). ISSN 0392-6672.

The Choranche Cave system (Vercors, France) is an excellent locality for measuring the growth rates of large numbers soda straws. This is especially the case for the Coufin Cave, as enlargement of the cave entrance in 1875 led to a change in stalactite color from brown to white, thus providing a reliable chronomarker. The date of this brown-to-white calcite transition has been confirmed by lamina counting. We measured and georeferenced the growth-lengths of 306 soda straws in a $1 \mathrm{~m}^{2}$ area of the roof of the Coufin Cave entrance chamber. Because of the very slow and sometimes inexistent water feeding of those stalactites, hydrochemistry analysis were not achieved and drop rate effect on growth were neglected; this study is based on a geomorphological and geostatistical work. By measuring a large number of soda straws in a very small area for which most of the parameters affecting stalactite growth could be considered uniform, and because flow rates are very slow (frequencies are always superior to 1 drop per half hour), we could ascribe differences in growth rates to variations in the global increase of water flow through the unsaturated matrix. Statistical and geostatistical analyses of the measurements showed that this set of similarly shaped stalactites actually consisted of three Gaussian populations with different mean growth rates: fast growth rate (FGR- mean of $0.92 \mathrm{~mm}^{-1} \mathrm{y}^{-1}$ ), medium growth rate (MGR- mean of $0.47 \mathrm{~mm} . \mathrm{y}^{-1}$ ) and low growth rate (LGR- $\left.0.09 \mathrm{~mm} . \mathrm{y}^{-1}\right)$. Plotting the lengths and spatial distribution of the 20 longest FGR soda straws revealed that there is a rough pattern to the water flow through the cave roof. Even if no direction is statisticaly different from others, the observed directional pattern is consistent with local and regional tectonic observations. Plots of the spatial distribution of the soda straws show that FGR soda straws follow lines of regional geological stress, whereas MGR and LGR soda straws are more dispersed.
\end{abstract}

Keywords: stalactite, karst, hydrogeology, growth rate, speleothem

Received 23 Decembre 2009; Revised 15 February 2010; Accepted 18 February 2010

\section{INTRODUCTION}

Stalagmites are often used for reconstructing paleoenvironments and paleoclimates. The dynamics of the speleothem record have been the subject of a number of studies, although most have focused on the geochemical record (Fairchild et al., 2000; Genty et al., 2001; Genty et al., 2002; Ramseyer et al., 1997; Verheyden et al., 1999, Fairchild et al., 2006, Spotl et al., 2005). Some researchers have investigated the hydrologic controls on speleothem growth (Baker et al., 2000; Baldini et al., 2006). Most of these studies were based on hydrologic stalactite series with sampling generally being limited to stalactites characterized by high flow rates allowing enough sampling for analyses. However, despite its implications for the use of stalactite records (sampling choices, interpretation, karst filtering effect), very little work has been done on flow distributions.

The literature on karst systems shows that differences in drainage and percolation govern both the location and the shape of stalactites (Ford and

1 Edytem, Université de Savoie - CNRS; Campus Scientifique, Savoie Technolac, F73376 Le Bourget du Lac - France, yves. perrette@univ-savoie.fr
Williams, 1989; Hill and Forti, 1997); Klimchouk et al., 2000). Most studies of the spatial distribution of speleothems in caves are relatively large scale. For instance, some of the main works on karstogenesis (Ford and Williams, 1989; Maire, 1990), associate stalactite location with classic growth parameters, such as the presence of soils with high partial pressure of $\mathrm{CO}_{2}$, water flow and partial pressure of $\mathrm{CO}_{2}$ in caves in relationship with the ventilation and the water flow in the cave (Bourges et al., 2006) . Cabrol (1978) showed that speleothem mineralogy is influenced by the final meters of the water path through the bedrock, and Hill and Forti (1997) correlated the main speleothem shapes with different feed water regimes, but neither study discussed the relationship between speleothems and karst drainage structure. Based on these results, some authors have used the mineralogy of speleothems to determine depositional contexts and thereby infer the environment outside the cave during speleothem formation (Borsato et al., 2000; Frisia et al., 2000).

However, only a few studies have described and discussed the spatial distribution of speleothems in a cave, or even in a chamber or passage of a cave. For example, as part of a study to calibrate speleothem paleoclimate isotope records, Verheyden et al. (1999) 
showed that the chemical behavior of the stalactite water supply was different at each sampling site. This observation, together with similar findings by Cabrol (1978), suggests that geology has a significant influence on water chemistry. Thus, stalactite shape and chemistry appear to be governed by the two main water flow processes in limestone: 1) porosity water flow, which tends to homogenize the growth, shape and chemistry of stalactites; 2) fracture network water flow, which usually causes heterogeneities in porosity resulting in variations in stalactite growth rate, shape and chemistry.

This work investigates the respective roles of these two processes by studying the spatial distribution of growth rates for a large population of stalactites in one small area of a cave. Our working hypothesis is the uniformity of cave ventilation and lithology at sampling site and site's position with respect to geological macro-structures (faults and diaclases) allowed us to assume that most of the variables affecting stalactite growth were fixed (ventilation, partial pressure of $\mathrm{CO}_{2}$, temperature, bedrock depth above the cave). Furthermore, due to the slow drip rates (faster drip frequencies are about 2 to 3 drops per hour but are commonly lower than one drop per hour), the continuance of the water feeding of stalactite by percolating water is assumed to be the only significant variable controlling stalactite growth in such a small area. Because this water flow is generally around the milli-hertz magnitude order, increasing growth rate by increasing drop interval (Baldini, 2001) can be exclude.

\section{SITE AND METHOD}

\section{Study site \\ Geological, geomorphological and geographical frame}

This work was carried out at Choranche, on the western side of the Vercors Mountains in southeast France. The Choranche system consists of three caves with more than $50 \mathrm{~km}$ of passages and chambers (see Figure 1). The system rises at the bottom of the Urgonian (Barremo-Bedoulian) escarpment that forms the northern side of the Bourne Gorge (Delannoy, 1981). Figure 2 shows the geological setting of the caves (Arnaud, 1966; Arnaud, 1981; Werner et al., 1980)

Although relics of pre-Miocene karstification have been observed on the plateau, the Choranche network mostly developed during the Pleistocene (Delannoy, 1997). The vertical structure of the karst (pits) is linked to the Vercors uplift (Alpine orogenesis). Geomorphological studies have shown that the River Bourne has been below the layer of impermeable marls since 300,000 years BP. Thus, the lithological base level on which the caves developed is higher than the regional hydrological base level. Studies of the structure, lithology and paleogeography of the Choranche hydrological network have shown it to be a vadose karst superimposed upon older phreatic and epiphreatic passages.

The elevation of the Choranche watershed ranges from 900 to $1400 \mathrm{~m}$ a.s.1. The vegetation covering the plateau changes with elevation from an oak and boxwood assemblage to a pine and beech assemblage. Where they exist, soils are typical calco-humic brown soils (Muxart, 1978). Mineralizations of infiltration measured on fast flows (from $1 \mathrm{hz}$ to continuous flow) of massive stalagmites in the entrance chamber show as supposed a calcite saturation index varying from 0.4 to 0.9 with a calcium concentration from 80 to $100 \mathrm{mg} \cdot \mathrm{l}^{-1}$ and a manganesium concentration always inferior to $0.5 \mathrm{mg} \cdot 1^{-1}$ (unpublished data). The continuous saturation of water is in accordance with the observation of continuous flowstone deposition. From an hydrological point of view, drop rate were monitored for fast flows (used for mineralization study) and slow flow ( faster soda straws) (Destombes et al., 1997, Perrette, 2000, Perrette et al., 2003). No relationship has been shown between rainfall and drop rate for sodastraws. The key control of these drop rate was found to be atmospheric pressure at the event time scale and high vs low flows at the year time scale. Those data are pertinent to give a general hydrological and hydrochemical background for infiltration waters in Choranche cave ; this information has to be applied cautiously to the soda straws whose water feeding are very low.

\section{A large number of sodastraws chronomarked in $\mathbf{1 8 7 5}$}

In $1875 \mathrm{AD}$, the Coufin Spring, which emerged from a scree slope, dried up. When the villagers started digging away the scree to find out what had happened to their water source, they discovered the previously unknown Coufin Cave (Gauchon, 1997). This excavation work enlarged the outlet from the cave, inducing a major change in the hydrological dynamics of the entrance chambers of the Choranche system. Before enlargement, the large entrance chamber was periodically subject to backflooding, which resulted in the stalactites being "dirtied" with clays. Since 1875, the entrance has been large enough to prevent backflooding; therefore, the stalactites are no longer "dirtied" by clays. Thus, the change of stalactite color from "dirty" brown to "clean" white provides an accurate chronomarker corresponding to 1875 (see Figure 3).

The research presented here is based on the measurement of growth rates for white calcite, that is to say, the parts of stalactites formed since 1875. As well as showing the "dirty" to "clean" color change, a feature of all the soda straws in the entrance chamber, Photo 1 also confirms the chronology of the transition. The stalactite in Photo 1 is about 10 centimeters long and has a diameter of between 5 and 8 millimeters. Two main parts (U1 and U2) can be distinguished: an upper, brown part (U1) that corresponds to growth before the discovery of the cave and a lower, white part (U2) that corresponds to growth after the cave entrance was enlarged. The white part can be further divided in two subsections (U2.1 and U2.2). Subsection U2.1 has a diameter of approximately 5 $\mathrm{mm}$ and a lamination interval of around $0.3 \mathrm{~mm}$ (zoom 1 in Photo1). The more recent subsection, U2.2, has a 




Fig. 1. Regional location map of the study area - the Choranche Caves in the Vercors Massif (France)

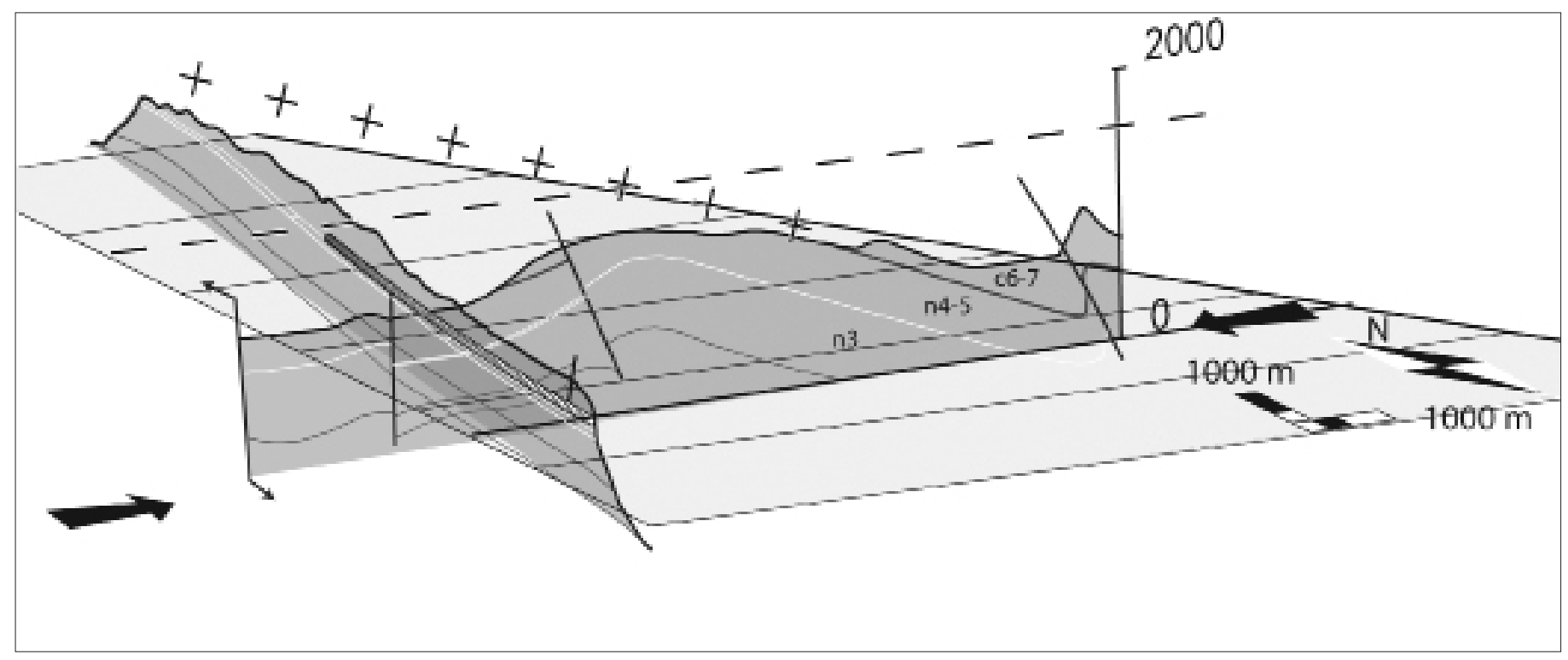

Fig. 2. Three-dimensional cross-section showing the location of cave passages.

Three-dimensional cross-section through the main strata of the Coulmes Plateau: (n3) Hauterivian marles; (n4-5) Barremo-Bedoulian Urgonian highly karstified strata; (c6-7): Senonian limestone. Some small benches have been omitted. A sketch tube shows the location of the main galleries, at the contact between the Urgonian limestone and the Hauterivian marles. In this area, the Pyrenean syncline (dotted line) and Alpine anticline (crossed line) are oriented north-south and east-west, respectively. The black arrows on the zero floor show the direction of the Alpine compression. Note that the two cross-sections intersect at around 1100m a.s.I. (from Arnaud, 1978) 




Figure 3: Location within the entrance chamber of the section of roof studied. The topography of the entrance room shows the proximity of the scarp. The three cross-sections show the general morphology of the room before entrance opening (upper), before ventilation by siphon lowering by cavers (2), and now(3).

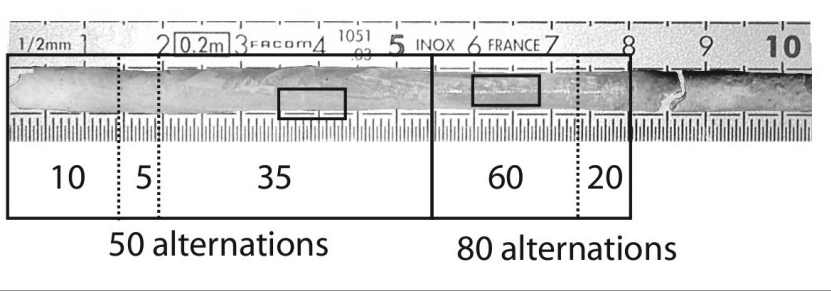

Photo 1. Soda straw from the entrance chamber, close to the study area (within a few meters). This soda straw is $8 \mathrm{~cm}$ long. The most recent part is on the left. The tan-colored right-hand section is "dirty" calcite formed before the cave entrance was enlarged in 1875. The lamina counts are shown in the rectangles. The boxed sections of the soda straw are shown in close-up in Photo 2 (right-hand box) and Photo 3 (left-hand box).



Zoom 1. U2.2-High growth rate lamination. The scale is five millimeters. Note the regularity of the annual lamination, which contrasts with the inter-annual thin laminae.



Zoom 2: U2.1 Low growth rate lamination.. The scale is five millimeters. Note the regularity of the annual lamination. diameter of around 7-8 $\mathrm{mm}$ and a lamination interval of almost $1 \mathrm{~mm}$ (zoom 2 in Photo 1). The transition between these two sub-sections correlates with the opening of a pseudo-siphon by cavers in 1948 . Although soda straw laminations have not often been used in paleoenvironmental reconstructions, they have been observed in many environments (Hill and Forti, 1997, Baker et al 2009). Given the regularity of the alternations including thiner irregular layers it is reasonable to assume that the laminations in the Coufin soda straws studied here are annual. Furthermore, doublet counting confirms the ages of the U1 to U2 transition (1875) and the U2.1 to U2.2 transition (1948).

\section{Study site location}

Figure 3 shows the location of the study area. The roof (about $1 \mathrm{~m}^{2}$ ) where measurements were taken is at the entrance to the Coufin Chamber (the show cave). The chosen sampling area was a very flat, homogeneous Urgonian bedding plane that is a product of the collapse roof of the entrance chamber. This bedding plane cleavage is part of the breakdown of the initial passage. The proximity of the scarp has applied very high tensile stresses to the joints, leading to the formation of a 20-meter diameter and 15-meter high chamber. As the soda straws studied here are located 2 meters above the lake and about 2 meters from the tourist path, they have not suffered from accidental breakage by people passing through the cave.

Choosing a small study area on a single flat and homogeneous bedding plane and a set of very low drip rate stalactite allowed us to discount most possible causes of growth rate variability. Growth rate variations between the 306 soda straws measured could therefore be assigned to differences in water flow. 


\section{Methods}

\section{Soda straw growth rate georeferencing}

The white section of every soda straw in the study area was accurately measured using a millimeter scale. The distance measured was from the tip of the soda straw to the bottom of the brown-white transition zone. This measure is referred to as the $Z$ value (in this case, $Z$ is not used to indicate an elevation). The measurement uncertainty was low and constant, and the length/error ratio increased with the length of the soda straw being measured.

Each soda straw was georeferenced by hanging a retroreflector directly beneath it and using a laser topographic measuring station to plot its exact position. We used a laser telemeter (Laser Technology Impulse 200) with a resolution of $10^{-2} \mathrm{~m}$ coupled with an electronic clinometer (precision of $0.1^{\circ}$, therefore measurement uncertainty was negligible) and an electromagnetic compass (Mapstar System Electronic Compass Module) with a resolution of $0.3^{\circ}$. The mean measurement distance was 5 meters; therefore, given an angular resolution of $0.3^{\circ}$, the maximum horizontal uncertainty was $2.510^{-2} \mathrm{~m}$. With this measurement method the overall horizontal measurement uncertainty is the product of both uncertainties (Protassov, 1999), that is to say, approximately $2.510^{-4} \mathrm{~m}^{2}$. Observer bias due to movement of the target hanging directly under the stalactite was about $5 \mathrm{~mm}$ for $\mathrm{X}$ and $\mathrm{Y}$. Each measurement point corresponds to the centroïd of an area of $410^{-4}$ $\mathrm{m}^{2}$. As the distributions of these uncertainties are normal, this area can be considered to be a disc (with a radius of $1.110^{-1} \mathrm{~m}$ ).

The whole data set comprises 305 measurements, 141 of which have a non-zero $Z$ value. The data were processed using Matlab software (The Mathworks, 2004).

\section{ANALYSES AND RESULTS}

The soda straw growth rate and georeferencing data were analyzed using a two-stage procedure. As a first stage, we carried out a statistical analysis of the growth rates of all the soda straws measured without taking into account their spatial distribution. The second stage involved a geostatistical study of the data set to examine possible correlations between soda straw growth rates and geographical location.

\section{Growth rate distribution}

The complete data set was plotted on a Gaussian probability graph (Figure 4). This graph was clearly non-linear, indicating that the complete data set could not be considered a single Gaussian distribution. The complete data set included soda straws with zero growth. Removing these zero values gave the same non-linearity and this was confirmed by Lilliefors and Jarque Bera tests at all significance levels (Conover, 1980). The zero growth soda straws were not included in the following analysis.

The goodness of fit of the central part of the distribution and the linearity of the tails of the



Fig. 4. Normal plot of the whole data set, with and without zero values. The abscissa shows the $Z$ values (growth lengths) and the ordinate shows their occurrence probability in a Gaussian distribution. If the data represented a true Gaussian distribution, the graph would be a straight line. This is not the case for the whole data set, but three straight-line segments can clearly be distinguished for the non-zero values.

probability plot suggested that the data set could be divided into three separate distributions.

Initially, we simply divided the data set at each change of slope. The results of this quick but effective division are shown in Table 1. Note the dispersion of the probability value between Lilliefors' modified version of the Kolmogorov Smirnov similarity test (K-S test) and the Jarque-Bera test (J-B test). The K-S test is based on the maximum difference between the observations and their theoretical value in a normal distribution with the same mean and standard deviation. The J-B test is more global in that it compares the third and fourth moments (skewness and kurtosis) of the whole set of observations and then establishes if these descriptive values are acceptable (Conover, 1980). For our data, the three new distributions, representing slow, medium and high growth rates, appear to be normal.

Table 1: Statistics for the three visually divided data subsets . Column $\mathrm{N}$ is the number of observations in the data subset. The K-S test is a Lilliefors test at $5 \%$ significance. The J-B test is a Jarque Bera test at the same significance level. The figures in grey show the $\mathrm{HO}$ acceptance (the distribution is not normal); $\mathrm{NaN}=$ non-algebraic number, not computed.

\begin{tabular}{|c|c|c|c|c|c|c|c|}
\hline & \multicolumn{2}{|c|}{ K-S test } & \multicolumn{2}{|c|}{$\mathrm{J}$-B test } & \multirow{2}{*}{$\mathrm{N}$} & \multirow{2}{*}{$\begin{array}{l}\text { Mean } \\
(\mathrm{mm})\end{array}$} & \multirow{2}{*}{$\begin{array}{l}\text { Std dev. } \\
\quad(\mathrm{mm})\end{array}$} \\
\hline & Test & $P$-val. & Test & $P$-val. & & & \\
\hline FGR & 1 & 0.01 & 0 & 0.07 & 35 & 93.2 & 10.9 \\
\hline MGR & 0 & $\mathrm{NaN}$ & 1 & 0.04 & 110 & 48.3 & 19 \\
\hline LGR & 1 & 0.03 & 0 & 0.19 & 43 & 9.7 & 4.8 \\
\hline
\end{tabular}

Table 2: Statistical values for the soda straw growth rate populations (NaN= non-algebraic number, not computed) (legend, see Table 1)

\begin{tabular}{|c|c|c|c|c|c|c|c|}
\cline { 2 - 8 } \multicolumn{1}{c|}{} & \multicolumn{2}{c|}{ J-B test } & \multicolumn{2}{c|}{ K-S test } & \multicolumn{1}{c|}{} \\
\cline { 2 - 8 } \multicolumn{1}{c|}{} & test & P-value & test & P-value & mean & std & N \\
\hline FGR & 0 & 0.060 & 1 & 0.018 & 92.5 & 11.1 & 39 \\
\hline MGR & 0 & 0.053 & 0 & 0.184 & 47.1 & 18.7 & 108 \\
\hline LGR & 0 & 0.159 & 1 & 0.026 & 9.3 & 4.6 & 42 \\
\hline
\end{tabular}


In order to check the validity of the three visually defined subsets, we used an iterative process to divide the data set into subsets (Judge et al., 1988). By arranging the growth rates in descending order, this iterative process allowed us use J-B and K-S tests for 5 to $\mathrm{N}$ observations to measure the significance of the subsets produced by each iteration. If the result of the statistical test is not significant, the observation can be considered to belong to the next distribution. The data were processed in descending order because of the field measurement bias, which decreases as stalactite length increases. The results of the J-B tests were used to define the three sub sets, as it was felt that the global analysis provided by the J-B test was more pertinent to the data set under consideration.

The results of this analysis are shown in Table 2. The validity of the J-B test typology was confirmed by the $\mathrm{p}$-values of the K-S tests for these sub-samples. These $\mathrm{p}$-values were superior to the $1 \%$ significance level in spite of the K-S test specificity. Figure 5 shows the resulting distribution for each subset of soda straw growth rates. These normal distributions all have short tails due to a bias produced by dividing the overall distribution according to soda straw length.

This analysis allows the soda straws to be divided into three groups according to their growth rate: low growth rate -LGR- (mean of $9.3 \mathrm{~mm} /$ century); medium growth rate-MGR- (mean of $47 \mathrm{~mm} /$ century); fast growth rate -FGR- (mean of $92 \mathrm{~mm} /$ century). It should be noted that this FGR is unusually high for a moderate altitude karst.

\section{Growth rate mapping}

Figure 6 is a map of the soda straws measured during this study with each soda straw allocated to one of three growth rate groups (slow, moderate and fast), shown by a different symbol. The size of the disk in the bottom right-hand corner of the diagram shows the spatial uncertainty mentioned above. The dimension of this figure is a non-terrestrial grid in meters. The Y-axis is aligned with magnetic north. The lines and inverted barbs show the boundaries of the bench containing the soda straws.

A preliminary examination of this map reveals a "window" (-a-) with no stalactites. This window is bounded by a number of FGR stalactites. Although the MGR, LGR and zero value $(Z)$ stalactites appear to be randomly clustered (grey areas in Figure 6), the groups of FGR are broadly linear. There are also a number of FGR doublets. The six doublets circled in Figure 6 are outside the LGR and MGR clusters.

In order to show the spatial distribution of growth rates, we interpolated these data using a linear Delaunay triangulation (Barber et al., 1996). The resulting shades-of-grey map is shown in Figure 7. The scale and north direction are the same. This type of spatial processing is unsatisfactory because it considers the distribution of soda straw growth rates to be a continuous phenomenon. Obviously, it is unrealistic to make such an assumption when studying a discontinuous phenomenon. Despite this weakness, this analysis method showed that the



Fig. 5. Normal plots of the three growth rate subsets

groups of FGR soda straws are broadly linear. The lines superimposed on Figure 7 show two bearings, $\mathrm{N} 50-60^{\circ}$ and $\mathrm{N} 130-140^{\circ}$, which may correspond to the diaclases in the region described by Werner et al. (1980). Our field measurements of joints and striae were in accordance with the presence of such structures. As the continuous mapping of soda straw growth rates revealed a general alignment for the FGR 




Fig. 6. Map of soda straw growth rates. The hatched area corresponds to an area without soda straws; the grey areas correspond to clusters of soda straws; the circles are the locations where FGR doublets are found. A small cross-section explains the reading of the barbed lines; the uncertainty disk shows the $X Y$ measurement uncertainty discussed in the text. Abscissa and ordinate units are meters.

stalactites, we applied simple geostatistical methods to confirm/clarify any spatial patterns in growth rate distribution.

\section{Geostatistical analysis of growth rate spatial distribution}

This analysis was based on the premises that the growth rate of a soda straw is related to the immediate environment in which it forms and that there are two types of water flow through unsaturated media: flow along discontinuities and porosity flow.

Although we did not carry out a variogram analysis of the spatial heterogeneity of the data set, especially window (a) (see Figure 6), we did perform a similar form of analysis that was more suited to our data set. This analysis was only carried out for the 20 soda straws with the fastest growth rates (target soda straws). Each of these targets was considered in turn, starting with the fastest growth. A circle was drawn around the target and the sum of the lengths and the number of soda straws in that circle were calculated. This was done in $5 \mathrm{~cm}$ steps for circles with radii from $5 \mathrm{~cm}$ to $30 \mathrm{~cm}$. The results were plotted as a graph of the number and lengths of the soda straws as a function of the radius of the circle. These graphs show the relation between the target FGR soda straw and the calcite growth surrounding it (see Figure 8A, upper diagram).



Fig. 7. Continuous mapping of soda straw growth rates

The rough lineation can be seen more clearly on this shades-of-grey map. The lighter greys correspond to the FGR and the darker greys correspond to the LGR. Abscissa and ordinate units are meters. The line corresponds to the bearings of the lineations.

A similar method was used to analyze the spatial distribution of the cumulative lengths and numbers of soda straws around each target (see Figure 8A, lower diagram). The results are given in the form of rose diagrams showing the pattern of soda straw numbers and total lengths in a $30-\mathrm{cm}$ radius circle. These rose diagrams show whether there is any preferential orientation for growth rates around the targets.

Given the non-normal distribution of the whole data set, all these geostatistical analyses were carried out using cumulative growth lengths and numbers of soda straws, rather than mean growth rates (cumulative growth divided by the number of soda straws), as it was felt that this would give more accurate results.

Although this analysis was carried out for the whole FGR data subset, we will limit our discussion to three representative results (the three results for the three fastest growth rate soda straws, presented in descending order and referred to as first, second and third). The positions of these three soda straws are shown in Figure 8B.

A preliminary visual analysis of the three circles and the three rose diagrams in Figure 8 shows that each data set is controlled by its proximity to the windows with no soda straws ('a' in Figure 6). However, the first FGR rose diagram shows the role of the south and east part which are distal from it. The graphs in Figure $8 \mathrm{~B}$ show the cumulative lengths and numbers of soda 


\section{Spatial distribution of stalactite sample (metric plane projection)}



Fig. 8. Geostatistical results of the three fastest FGR. Two graphs are shown for each of the three fastest FGR (fastest of the three growth rates on the left, slowest on the right): a cumulative plot and a rose diagram. The upper graph shows the cumulative length and number (dotted line) of soda straws as a function of the distance from the FGR soda straw. Data are rough without correction of the area evolution.

The rose diagram shows the same data as a function of the direction to the north in the final $30 \mathrm{~cm}$ radius circle. Note the shape of the right-hand rose diagram, which reveals the presence of a cluster of soda straws around N340 and N40 more important in the number of soda straws.

straws as a function of distance from the target. For the first and third soda straws there is a decrease in growth in the area immediately surrounding the target. This phenomenon was noted for the majority of the targets. This is in contrast to the graph for the second soda straw, which shows a growth cluster immediately surrounding the target. However, all three targets are characterized by an increase in soda straw length and numbers at a radius of around $20 \mathrm{~cm}$, and then a decrease in both parameters as the radius increases to $30 \mathrm{~cm}$. Although we cannot definitively rule out process bias (the total stretch of the set), similar distributions were observed for all the FGR soda straws. Finally, the three rose diagrams clearly 
show preferred orientations, although they must be treated with caution given the first observation and the weight of the clusters for the third FGR. Whatever, the general bearings of the data set are shown for the first and second FGR.

Figure 9 presents a synthesis of the FGR analysis, combining the rose diagrams for all the FGR subsets. Anova test have been achieved for different set of data (only FGR, FGR and MGR). These tests show no statistical difference between bearings. This statistical result may be linked to the two small number of FGR sodastraws or to the empty surface in the studied area. However, the combined rose diagram of growth rate numbers shows a vague structure for both plots (N130 and N45) in accordance with those shown by the Delaunay interpolation of the growth (see above).

In summary, we observed a general decrease in soda straw growth in the immediate vicinity of the 20 fastest growth rate soda straws, with the exception of the FGR doublets. In addition, for each of the seven fastest growth rates, soda straw numbers and growth lengths peak at a distance of around $15 \mathrm{~cm}$ from the target.

\section{DISCUSSION: TOWARDS A SMALL-SCALE MODEL OF STALACTITE WATER SUPPLY}

It is important to underline the specific nature of the group of stalactites studied here. This growth rate population only represents a very small fraction of the diversity of shapes observed underground. These results are also specific to their location, which is very distinctive in terms of its massive and "pure" Urgonian limestone bedrock, its location near the entrance of an unconfined alpine cave with moderate water mineralization, and its position at the bottom of the 300 meter-high scarp of the Bourne Gorge, a position synonymous with the release of mechanical stresses. This structural context amplifies the influence of hydrogeology on soda straw growth rates.



Fig. 9. Cumulative rose diagram. Rose diagram combining the plots for the 20 fastest FGR (see figure 10). No clear structure of these rose plots separately from the two slackened direction of N30 and N 110 which aren not statistically significant (ANOVA test).
At first, this work demonstrates the interest of a geomorphological and geostatistical study to improve our knowledge of the spatial distribution of growth rate. This work shows that within a small area, three stalactite populations are mixed with the same macroscopic morphology. In this specific case of slow drip rates, these three populations are relinked to their water feedings more or less continuous. This geomorphological approach allows too to improve the knowledge of the water supply of stalactite which are sometimes dry and then which are unstudied by hydrochemistry methods.

More cautiously, it is also interesting to note that the distribution of the FGR stalactites appears to be coarsely structured, whereas the distributions of the MGR and LGR stalactites appear to be random. If it was confirmed by other modeling or in the field hydrochemical or geomorphological studies, the difference between a slackened structural distribution of FGR and a randomly clustered MGR and LGR could be readily ascribed to a decrease in hydrostatic pressure and an increase in the amount of water available in joints or other enlarged voids. This very simple model is based on the variable capacity of limestone to hold water. Bisson and Lehr (2004) showed that the hydraulic conductivity of fractured or jointed limestones is at least one order of magnitude greater than the one of unfractured porous limestones. Such studies should be developed to help in the sampling strategy and in the interpretation of speleothem for environemental and paleo-environemental studies.

\section{ACKNOWLEDGMENTS}

This work was carried out with the support of the Choranche Show Cave Company. In particular, the initial question of soda straw mean growth rates was raised by a cave guide. The authors thank the editor and reviewers for the help in improving the paper. We would also like to thank Estelle Ployon, Paul Henderson and Jean-Luc Destombes for their critical and constructive reading of the manuscript.

\section{REFERENCES}

Arnaud H., 1966 - Contribution à l'étude géologique des plateaux du Vercors méridional. Géologie alpine, 32: 34-51.

Arnaud H., 1981 - De la plate-forme urgonienne au bassin vocontien : Le Barrèmo-Bédoulien des Alpes occidentales entre l'Isère et le Buëch (Vercors méridional Diois oriental et Dévoluy). Géologie alpine, Mémoire spécial, 12, $804 \mathrm{p}$.

Baker A., Genty D. \& Fairchild I.J., 2000 - Hydrological characterisation of stalagmite dripwaters at Grotte de Villars, Dordogne, by the analysis of inorganic species and luminescent organic matter. Hydrology and Earth system sciences, 4(3): 439-449.

Baker A., Fuller L., Genty D., Fairchild I.J, Jex C. \& Smith C.L., 2009 - Annually Laminated Speleothems: a Review. International Journal of Speleology, 37(3): 193-206.

Baldini J.U.L., McDermott F. \& Fairchild I.J., 2006 Spatial variability in cave drip water hydrochemistry: Implications for stalagmite paleoclimate records. Chemical Geology, 235(3-4): 390-404. 
Baldini J.U.L., 2001 - Morphologic and dimensional linkage between recently deposited speleothems and drip water from Browns Folly Mine, Wiltshire, England. Journal of Cave and Karst Studies, 63(3): 83-90.

Barber C.B., Dobkin D.P. \& Huhdanpaa H.T., 1996 - The Quickhull Algorithm for Convex Hulls. ACM Transactions on Mathematical Software, 22(4): 469-483.

Bisson R.A. \& Lehr J.H., 2004 - Modern Groundwater Exploration: Discovering New Water Resources in Consolidated Rocks Using Innovative Hydrogeologic Concepts, Exploration, Drilling, Aquifer Testing and Management Methods. Wiley, 328 p.

Borsato A., Frisia S., Jones B. \& Van Der Borg K., 2000 - Calcite Moonmilk: Crystal Morphology and Environment of Formation in Caves in the Italian Alps. Journal of Sedimentary Research, 70(5): 1171-1182.

Bourges F., Genthon P., Mangin A. \& D'Hulst D., 2006 Microclimates ofl'aven d'Orgnac and other french limestone caves (Chauvet, Esparros, Marsoulas). International Journal of Climatology, 26 (12), 1651-1670.

Cabrol P., 1978 - Contribution à l'étude du concrétionnement carbonaté des grottes du sud de la France, morphologie, génèse, diagénèse. CERGH, Univ. Montpelliers, 275 p.

Conover W.J., 1980 - Practical Nonparametric Statistics. Wiley, New York, 511 p.

Delannoy J.-J., 1981 - Le Vercors septentrional : le karst de surface et le karst souterrain. Tome II, , Thèse de troisième cycle, Univ. Joseph Fourier, Grenoble I.

Delannoy J.J., 1997 - Recherches géomorphologiques sur les massifs karstiques du Vercors et de la transversale de Ronda (Andalousie). Les apports morphogéniques du karst. Thèse de Doctorat d'Etat, Univ. Grenoble.

Destombes J.L., Cordonnier M., Gadat J.Y. \& Delannoy J.J., 1997 - Periodic and aperiodic forcing of water flow through sodastraw stalactites. Proc. 12th Int. Congr. Speleol., La Chaux-de-Fonds, 2: 69-73.

Fairchild I.J., Borsato A., Tooth A.F., Frisia S., Hawkesworth C.J., Huang Y., McDermott F. \& Spiro B., 2000 - Controls on trace element ( $\mathrm{Sr}-\mathrm{Mg}$ ) compositions of carbonate cave waters: implications for speleothem climatic records. Chemical Geology, 166(3-4): 255-269.

Fairchild I.J., Tuckwell G.W., Baker A. \& Tooth A.F., 2006 Modelling of dripwater hydrology and hydrogeochemistry in a weakly karstified aquifer (Bath, UK): Implications for climate change studies. Journal of Hydrology, 321(1-4): 213-231.

Ford D.C. \& Williams P.W., 1989 - Karst geomorphology and hydrology. Unwin Hymann, London, 601 p.

Frisia S., Borsato A., Fairchild I.J. \& McDermott F., 2000 - Calcite Fabrics, Growth Mechanisms, and Environments of Formation in Speleothems from the Italian Alps and Southwestern Ireland. Journal of Sedimentary Research, 70(5): 1183-1196.

Gauchon C., 1997 - Des cavernes et des hommes. géographie souterraine des montagnes françaises. Karstologia Mém., 7: 247 pp.

Genty D., Baker A., Massault M., Proctor C., Gilmour M., Pons-Branchu E. \& Hamelin B., 2001 - Dead carbon in stalagmites: carbonate bedrock paleodissolution vs. ageing of soil organic matter. Implications for $13 \mathrm{C}$ variations in speleothems. Geochimica et Cosmochimica Acta, 65(20): 3443-3457.
Genty D., Plagnes V., Causse C., Cattani O., Stievenard M., Falourd S., Blamart D., Ouahdi R. \& Van-Exter S., 2002 - Fossil water in large stalagmite voids as a tool for paleoprecipitation stable isotope composition reconstitution and paleotemperature calculation. Chemical Geology, 184(1-2): 83-95.

Hill C.A. \& Forti P., 1997 - Cave Minerals of the World. National Speleological Society, Huntsville, 463 p.

Judge G.G., Hill R.C., Griffiths W.E., Lutkepohl H. \& Lee T.-C., 1988 - Introduction to the Theory and Practice of Econometrics. Wiley, New York, 1064 p.

Klimchouk A.B., Ford D.C., Palmer A.N. \& Dreybrodt W., 2000 - Speleogenesis and Evolution of Karst Aquifers. National Speleological Society, Huntsville, Alabama, 527 p.

Maire R., 1990 - La haute montagne calcaire. Karstologia Mémoire, 3: 731 p.

Muxart T., 1978 - Note sur l'agressivité potentielle des eaux de percolation de différents sols dans le Vercors, en fonction de la nature de la couverture végétale. Revue de Géographie Alpine, 66(2): 173181.

Perrette Y. Delannoy J.J \& Vandemeulebrouck J., 2003 - Spatial homogeneity of speleothem records, hydrological and geomorphological approach. In: Climate Changes, the Karst Record III, Abstract Volume, Montpellier, 127-128.

Perrette Y., 2000 - Etude de la structure interne des stalagmites : contribution à la connaissance géographique des évolutions environnementales du Vercors (France). Développement et application d'une approche multiparamètre des archives stalagmitiques. Thèse d'université Thesis, Université de Savoie, Chambery, 324 p.

Protassov K., 1999 - Probabilités et incertitudes dans l'analyse des données expérimentales. Collection Grenoble Sciences. Presses Universitaires de Grenoble, Grenoble, 128 p.

Ramseyer K., Miano T.M., D’Orazio V., Wildberger A., Wagner T. \& Geister J., 1997. Nature and origin of organic matter in carbonates from speleothems, marine cements and coral skeletons. Organic Geochemistry, 26(5): 361-378.

Spötl C., Fairchild I.J. \& Tooth A.F., 2005 - Cave air control on dripwater geochemistry, Obir Caves (Austria): Implications for speleothem deposition in dynamically ventilated caves. Geochimica et Cosmochimica Acta, 69: 2451-2468.

The Mathworks, I., 2004. Matlab 7 (R14). In: I. The Mathworks (Editor).

Verheyden S., Keppen E., Quinif Y. \& Genty D., 1999 - Holocene palaeoclimatic and palaeo-environmental reconstruction inferred from stable isotopic and geochemical studies in Belgian caves and tunnels. Proceedings of the "Karst 99" Symposium (Mende, September 10-15): 202-208.

Werner P., Horrenberger J.-C. \& Ruhland M., 1980 - Evolution géométrique et cinématique du secteur des gorges de la Bourne (Vercors septentrional) Déformation de bancs massifs dans une zone en chevauchement - décrochement. Sci. Géol. Bull., 33(4): 193-202. 